\title{
Static and Dynamic Analysis of Transmission Line Tower
}

\author{
D.Leela, Dasarathy, A . K. , Leshmi mohan, S.Kabileshwar
}

\begin{abstract}
The towers of the to the most powerful life-line buildings that support electrical transmission line are peculiar transmission. Transmission towers are essential for providing energy to various parts of the nation. The transmission line should be stable and carefully structured with the objective that they do not fizzle in the midst of a cataclysmic event and adapt to the national and universal standard. This present paper manages the investigation of static and dynamic examination of transmission line tower. A run of the mill sort of transmission line tower is picked as contextual analysis . The examination and displaying of pinnacle is done utilizing FE based ANSYS programming. The heaps following up on the pinnacle reflected are numb burden, live burden and dynamic burdens in this Paper the most extreme twisting joined anxieties and characteristic frequencies, bowing minute shear constrain are gotten.
\end{abstract}

Key words ; static analysis, dynamic analysis, ANSYS, transmission tower

\section{INTRODUCTION}

The want of electric power utilization has kept on expanding in each nation, the speed of interest being more prominent in the creating nations. The towers of the transmission line are some of the most important life-line buildings that assist spread electrical power. Transmission towers are essential for providing authority to the country's various districts. In the current scenario, the structure of intensity stations increases and consequently increases the power transmission lines from the generating stations to the distinguishing angles.Interconnections between frameworks are likewise expanding to upgrade dependability and economy. The present examination manages normal frequencies, methods of vibration, diversion design exposed to live load and wind load following up on pinnacle And static and dynamic investigation of transmission line tower.

\section{NECESSITY OF TRANSMISSION LINE TOWER}

The transmission line tower is progressively fundamental now daily since entire world utilizing most extreme measure of power. without power no any organization will run. Every single MNC need the power to run their work.

Revised Manuscript Received on October 12, 2019

Dr.Dasarathy, Professor in the Vel Tech Multi Tech Dr. Rangarajan Dr. Sakunthala Engineering College Department Of Civil Engineering

Leela D, Teacher ,M.G.R Educational and Research Institute. Chennai

Lekshmi Mohan, Mtech Construction Engineering and Management from Dr. M. G. R Educational and Research Institute, Chennai.

S.Kabileshwar, Mtech Construction Engineering and Management from Dr. M. G. R Educational and Research Institute, Chennai.
The reason for a transmission line tower is to assist conveyors transmitting electrical power and a few ground cables at suitable separations above ground level and from each other. The transmission line towers cost about 35 to $45 \%$ of the transmission line's total price. A tower for transmission is a space aid and an unclear structure. The transmission line tower provides high present voltage. We need a transmission line tower to offer elevated present voltage. A high-voltage transmission line tower is the most perfect method to supplying high present voltage.

Objective of this paper

$>$ To determine Deflection profile and member forces

$>$ Arrive Natural frequency, Bending moment and Deformation

Input geometric data

$$
\begin{aligned}
& >\text { Height }-40 \mathrm{~m} \text { (base level) } \\
& >\quad \text { Length }-20 \mathrm{~m} \text { (base level) } \\
& >\quad \text { L-type bracing system }
\end{aligned}
$$

Properties of stainless steel

$\circ$ L-type of cross section

$\circ$ Width of L section $=\quad 0.1 \mathrm{~m}$

$\circ$ Thickness of L section $=\quad 0.01 \mathrm{~m}$

Loads apply on tower

UDL(uniformly distributed load $)=-500 \mathrm{~N}$

Wind loads $=-50 \mathrm{~N}$

\section{About ANSYS}

ANSYS V.18.1 is a coordinated pre-and postprocessor plan investigation device based on the FEM created by ANSYS. The ANSYS item documentation is beautiful and includes reference instructions; guiding, displaying and fitting aid operations; controlling vital research strategies; managing driven exams; component reference; hypothesis reference; auxiliary examination manage; warm investigation direct; electromagnetic fields investigation manage; liquid elements manage; and coupled field investigation direct.

Taken together, these manuals describe the techniques, instructions, elements and hypothetical subtleties that the ANSYS program is supposed to use. ANSYS is used to check the transmission line tower. Apart from the ANSYS hypothesis reference, most of the above manuals are available online via the ANSYS help framework, which can be accessed either as an independent framework or from within the ANSYS program.ANSYS is a completed programming set of FEA reproduction produced by ANSYS Inc-USA. Dr. JOHN SWANSON founded the organisation in 1970 and originally named Swanson Analysis Frameworks; Inc. 
ANSYS is the company items ' first name. to handle unusual problems of reason. ANSYS has a large group of products that are developed

\section{METHODOLOGY, PROCEDURE AND DATA OBSERVATION}

All were presented in figurative way

Step 1 Geometry part

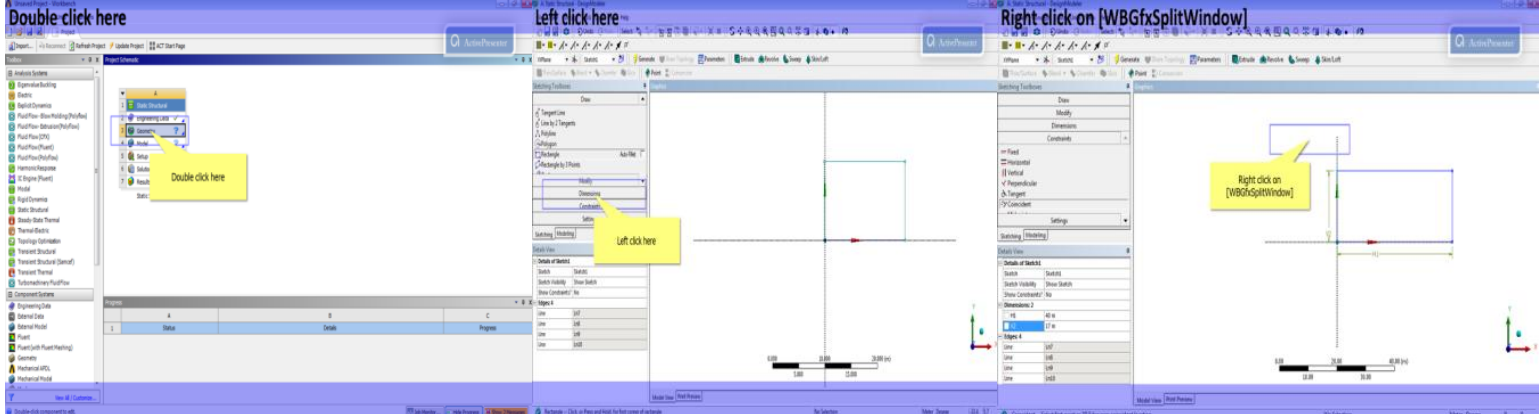

Step 2Modelling
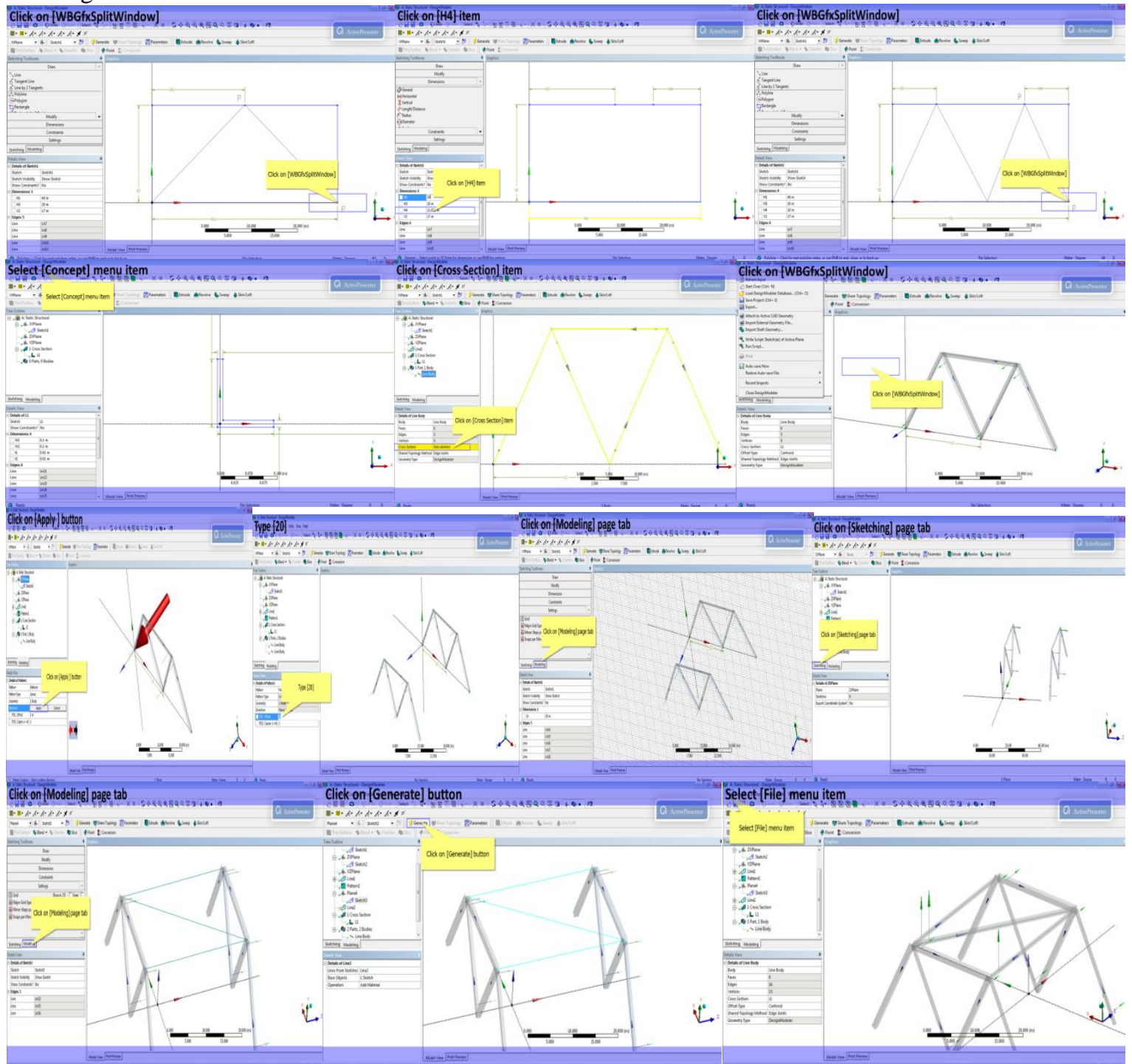

Step 3:Meshing 


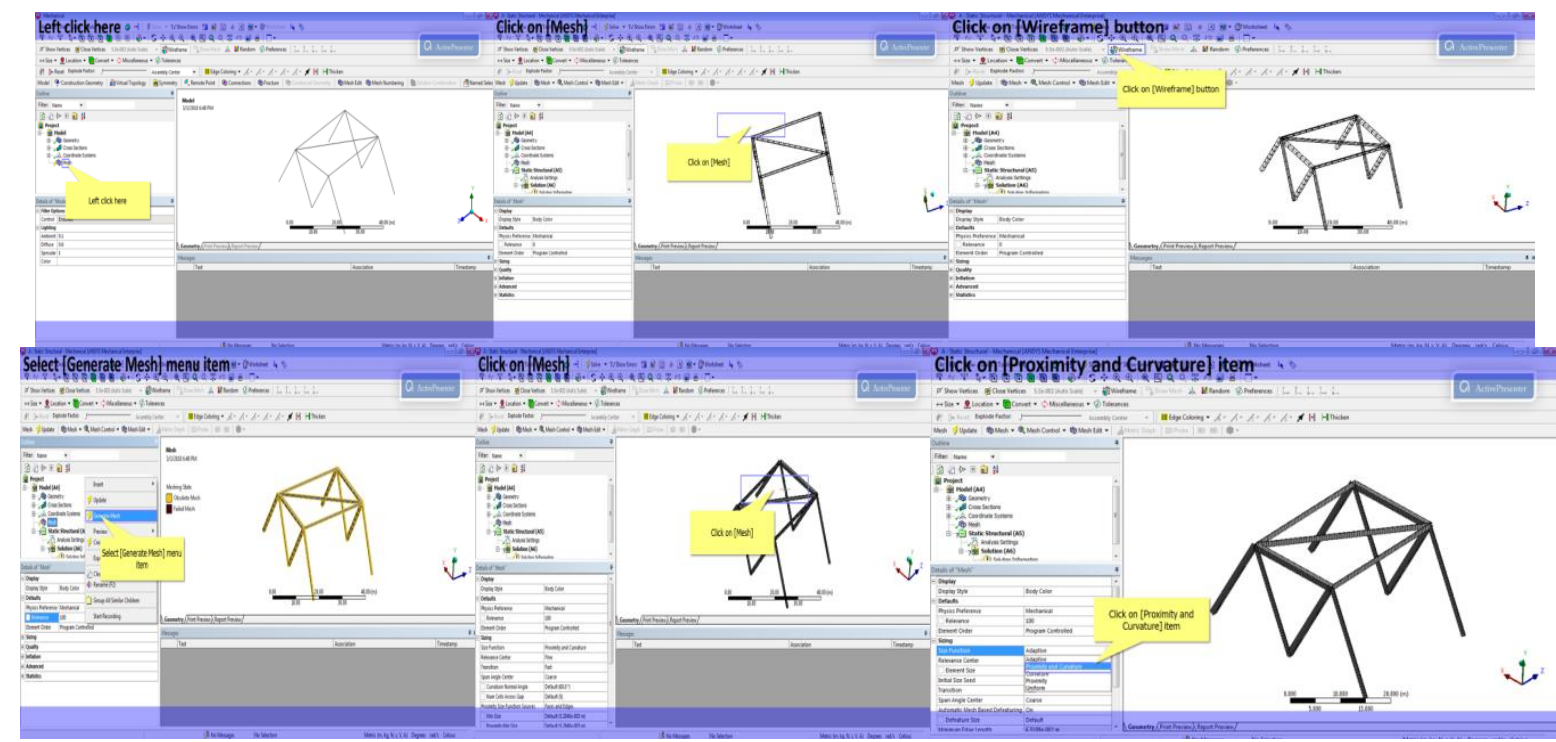

Step 4:Static structure

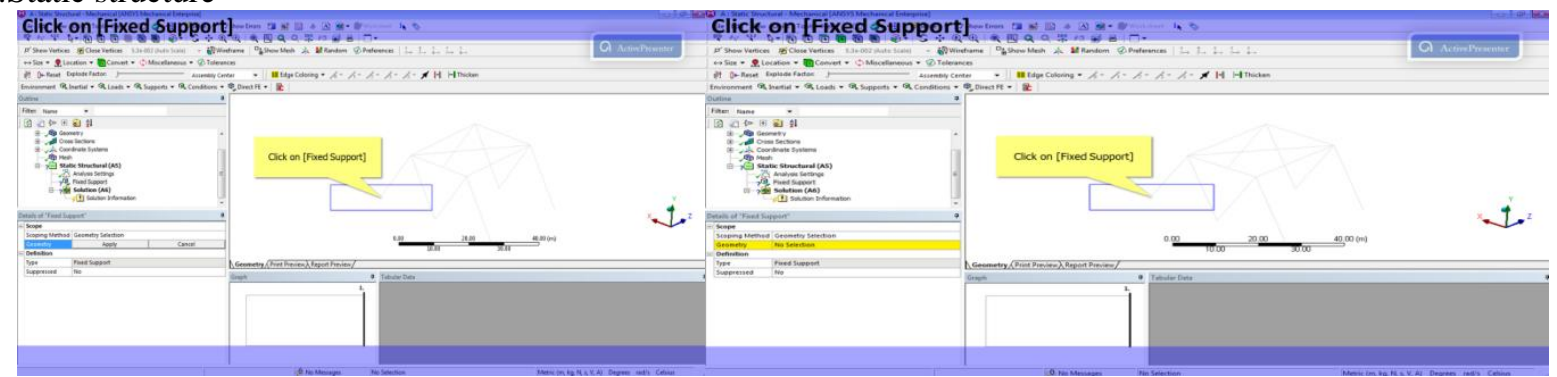

Step 5:Solution

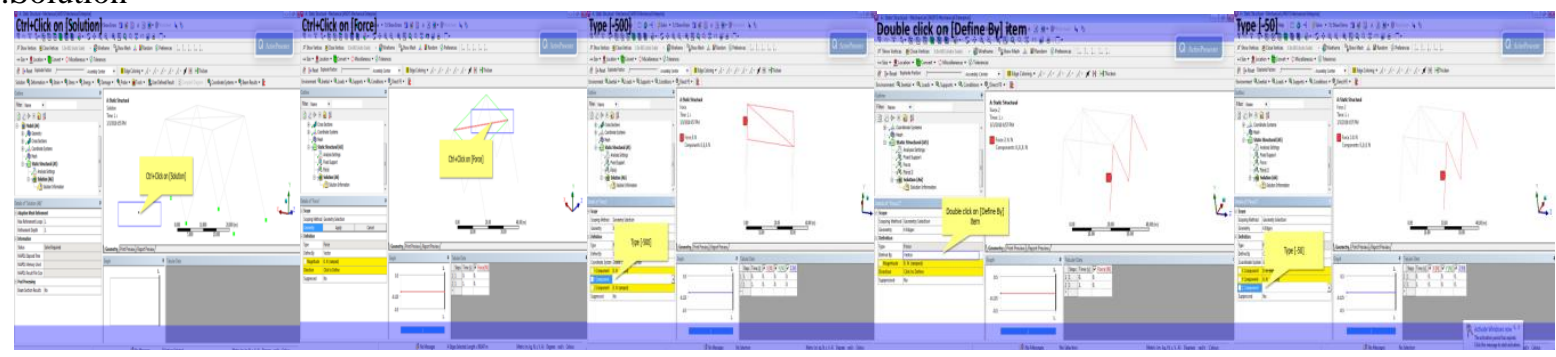

Step 6:Result

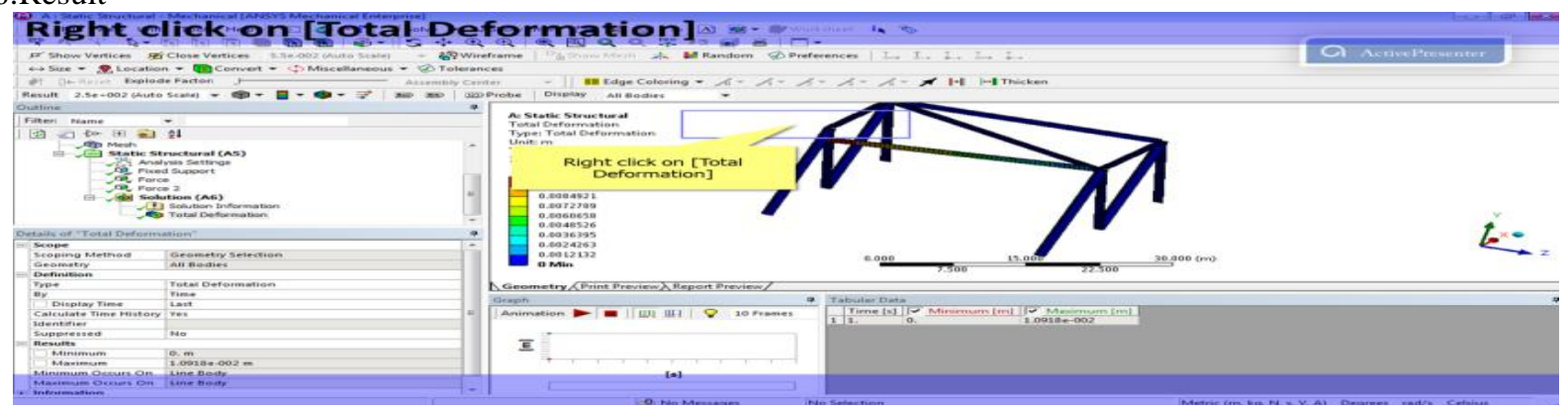

\section{STATIC STRUCTURE}

A static structural analysis fixes the shear force, bending moment \& displacements in structures or constituents affected by loads that do not prompt major inertia and damping things. UDL and wind load are anticipated; that is, the loads and the structure's retort are presumed to fluctuate gently with respect to time. A static structural load can be executed using the ANSYS. The following tables shows the result of Shear force, Bending moment \&displacement of tower

Table 1 Sample of Result of Shear force, Bending moment \& Total displacement)

\begin{tabular}{|c|c|c|c|}
\hline $\begin{array}{l}\text { Length }[\mathrm{m}] \\
\mathrm{o} .\end{array}$ & $\begin{array}{c}\text { Total Shear Force [N] } \\
64.217\end{array}$ & $\begin{array}{l}\text { Total Bending Moment }[\mathrm{N} \cdot \mathrm{m}] \\
240.52\end{array}$ & \begin{tabular}{|c} 
Total Displacement $[\mathrm{m}]$ \\
$5.3852 \mathrm{e}-008$
\end{tabular} \\
\hline 0.48766 & $64.21 \%$ & 209.81 & $2.4202 \mathrm{e}-007$ \\
\hline 0.97532 & 61.966 & 180.38 & $4.5146 e-007$ \\
\hline 1.463 & 59.714 & 152.32 & $6.79 \mathrm{e}-007$ \\
\hline 1.9506 & 57.462 & 125.77 & $9.2266 e-007$ \\
\hline 2.4383 & 55.21 & 101. & 1.1803e-006 \\
\hline 2.926 & 52.959 & 78.596 & $1.4495 \mathrm{e}-006$ \\
\hline 3.4136 & (30) & 59.786 & $1.7279 \mathrm{e}-006$ \\
\hline 3.9013 & 40.405 & 47.218 & $2.013 e-006$ \\
\hline 4.3889 & 40.205 & 44.579 & $2.3025 e-006$ \\
\hline 4.8766 & 43.952 & 51.953 & $2.5939 \mathrm{e}-006$ \\
\hline 5.3643 & 41.7 & 64.991 & $2.8849 \mathrm{e}-006$ \\
\hline
\end{tabular}

Published By:

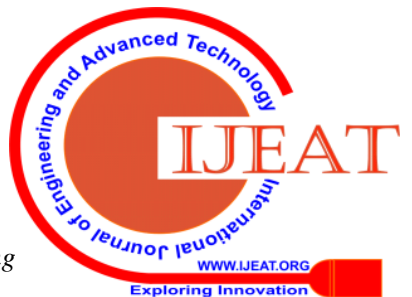


Figure 1 show Shear force, Bending moment \& Displacement of tower)

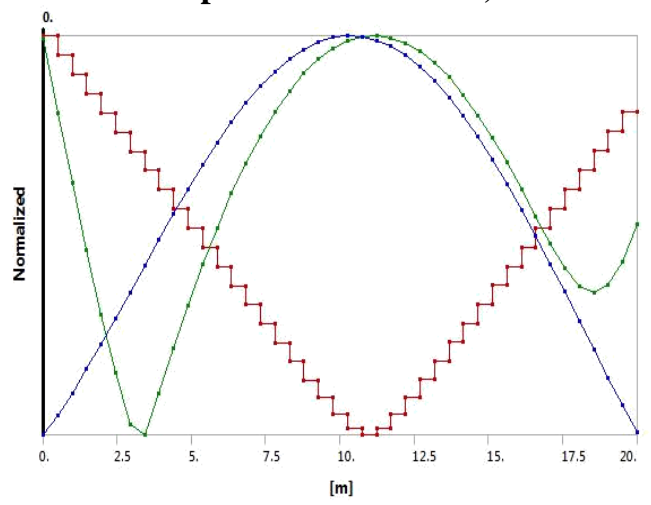

Shear force value

\section{Vibration analysis:}

Vibration scrutiny is a method of eyeing for glitches and checking customary vibration signature change from the of a system. The
Minimum =1.0837 N@14.142 m

Maximum $=64.217 \mathrm{~N} @ 0 \mathrm{~m}$

Bending moment value Minimum value =44.425 N-m @ $23.895 \mathrm{~m}$

Maximum value $=240.52 \mathrm{~N}-\mathrm{m} @ 0 \mathrm{~m}$

Displacement Minimum value =5.7026 $\mathrm{e}^{-8} @ 28.284 \mathrm{~m}$

Maximum value $=1.1803 \mathrm{e}^{-6} @ 2.4383 \mathrm{~m}$ vibration of every piece in motion is described by deviations of amplitude, intensity, and frequency. All are represented in Table and figures

Table 2 show Total deformation 1,2 and 3

\begin{tabular}{|l|l|l|l|}
\hline Mode & \multicolumn{3}{|c|}{ Frequencies $(\mathrm{Hz})$} \\
\hline & \multicolumn{1}{|c|}{1} & \multicolumn{1}{c|}{2} & \multicolumn{1}{c|}{3} \\
\hline 1. & 1.398 & 1.398 & 1.398 \\
\hline 2. & 4.0215 & 4.0215 & 4.0215 \\
\hline 3. & 4.6728 & 4.6728 & 4.6728 \\
\hline 4. & 5.6113 & 5.6113 & 5.6113 \\
\hline 5. & 5.8862 & 5.8862 & 5.8862 \\
\hline 6. & 6.0139 & 6.0139 & 6.0139 \\
\hline 7. & 6.027 & 6.027 & 6.027 \\
\hline 8. & 6.0859 & 6.0859 & 6.0859 \\
\hline 9. & 6.2165 & 6.2165 & 6.2165 \\
\hline 10. & 6.3765 & 6.3765 & 6.3765 \\
\hline
\end{tabular}

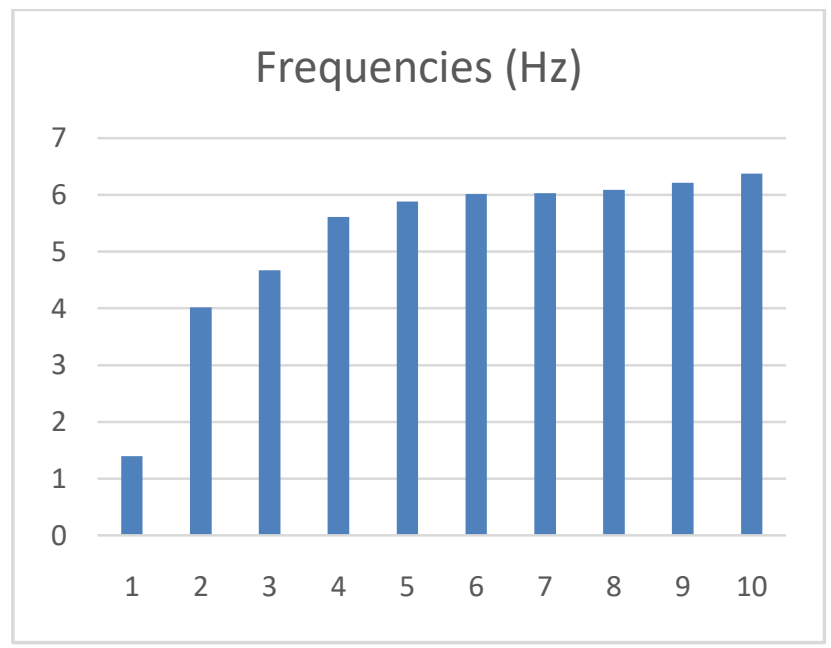

Figure 3 Corresponding Frequency 
Table 3 Results of deformation

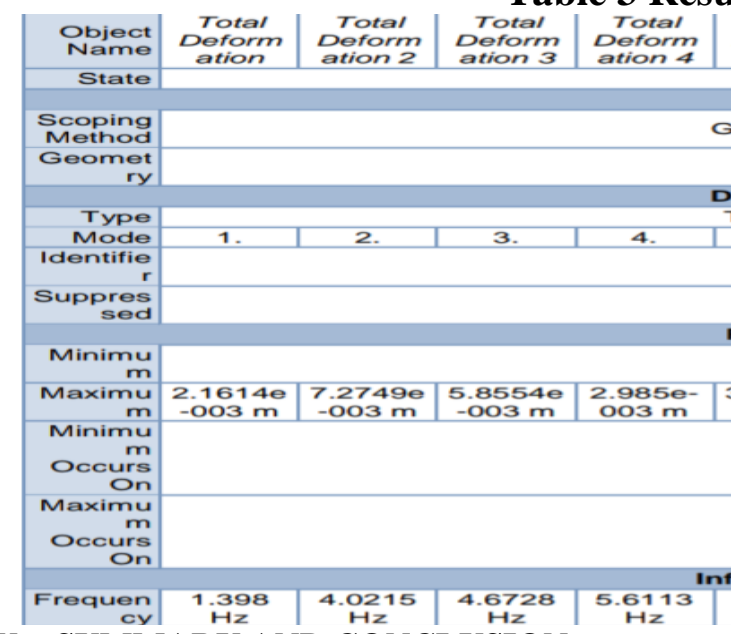

V. SUMMARY AND CONCLUSION

The static and dynamic examination of transmission line tower (L-kind of cross area) An endeavor has been made in investigation and demonstrating of transmission line tower utilizing limited component and on based ANSYS programming. The models made by utilizing

ANSYS workbench programming. The connection component is utilized for the displaying. In the present investigation the social changes because of diversion and worries of transmission line tower against static and dynamic loadings is completed. Following are the ends drawn from the examination.

$>$ The Value of Maximum miss happening got on account of static investigation is $7.2749 \mathrm{e}-003(\mathrm{~m})$

$>$ In free vibration investigation of existing transmission line tower of L-kind of cross area.

$>$ As the quantity of mode is expanded, the estimation of normal frequencies progressively

increments. For initial three modes, the regular recurrence remains practically steady and from that point increments in higher modes.

The investigation completed utilizing limited component examination (ANSYS programming) gives fitting arrangements including nodal, component, and part arrangements

\section{REFERENCES}

1. Karthik S. Sowjanya G.V [2015] "Static and dynamic analysis of transmission line tower under seismic loads", International Journal of Engineering Research \& Technology (IJERT), Vol. 4 Issue 08, pp no 29-33.

2. Mujamil, Banulatha G. N, Narayan. G, Rajeeva S.J [2015] "Dynamic analysis of transmission line tower for different sectional properties with fluid viscous dampers" International Journal of Advanced Research in Education Technology (IJARET), Vol. 2, Issue 2, pp no 134-137.

3. Sakthivel. T and Sanjeevi R [2015] "Analysis and Design of multi circuit transmission line tower" International Journal of Emerging Technology in Computer Science \& Electronics (IJETCSE), Volume 13 Issue 1, pp no 5661

4. GopiSudamPunse [2014] "Analysis and design of transmission line tower" International OPEN ACCESS Journal of Modern Engineering Research (IJMER), Vol. 4, Issue.1, pp no 116-138.

5. Srikanth L, Neelima Satyam D [2014] "Dynamic analysis of transmission line towers" International Journal of Civil, Environmental, Structural, Construction and Architectural Engineering Vol:8, No:4, pp no 434-437.

6. Pahwa S, Tiwari V, Jatwa H [2014] "Analytical study of transmission tower subjected to wind and seismic loads optimization technique" International Journal of Emerging

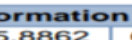

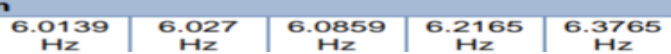
Technology and Advanced Engineering, Volume 4, Issue 9, pp no 375-383.

7. Panchal D. R. [2014] "Various transmission tower analysis and design using professional software" International journal of innovative research \& development (IJIRD), Vol 3 Issue 7, pp no 107-112.

8. McClure G, Lapointe M [2003] "Modeling the structural dynamic response of overhead transmission lines" Computers and Structures 81, pp no 825-834.

9. Raghavendra T [2012] "Computer aided analysis and structural optimization of transmission line towers" International Journal of Advanced Engineering Technology, (IJAET), Vol.3, Issue 3, pp no 44-50.

10. Addala G, Satyam D. N and Kumar R. P [2010] "Dynamic Analysis of transmission towers under strong ground motion" Proceedings, 3rd International Earthquake Symposium, Bangladesh, Dhaka.

11. SudheerCh, Rajashekar K, Reddy P. P, BhargavaGopi Krishna Y [2013] "Analysis And Design Of 220kv Transmission Line Tower In Different Zones I \& V With Different Base Widths - A Comparative Study", International Journal of technology enhancements and emerging engineering research, vol 1, issue 4, pp no 3543

12. Chandran R, Mathew L. A [2016] "Model and Seismic Analysis of Transmission Tower with I, C and Circular Sections Using Finite Element Analysis", International Journal of Science and Research (IJSR), Volume 5 Issue 7, July 2016, pp no-1297-1300.

13. Varakavi V. T. R, Arunakanthi E [2016] "Dynamic Analysis of Electrical Transmission Line Towers", International Journal of Engineering Science and Computing (IJESC), Volume 6 Issue No. 7, pp no 1739-1744.

14. ANSYS Mechanical APDL Structural Analysis guide \& ANSYS Reference Guide.

15. IS: 5613 (Part 3/Sec 1): 1989 Code Of Practice For Design, installation And Maintenance For Overhead Power Lines, Part 3 400 KV Lines, Section 1 - Design.

16. Indian Standard "Code of practice for design loads (Other than earthquake) for buildings and structures” IS: 875 (Part 3) 1987(Reaffirmed 1997).

17. IS 1893 (Part 1): 2002 Criteria for earthquake resistant design Structures.

18. IS 1893 (Part 4): 2005 Criteria for earthquake resistant design Structures. Part 4- industrial structures including stack-like Structures.

19. IS 802(Part 1/Section 1)-1995, Bureau of Indian Standards Use of structural steel in over head transmission line towers - code of practice (materials, loads and permissible stresses), Sec.1 Materials and Loads.

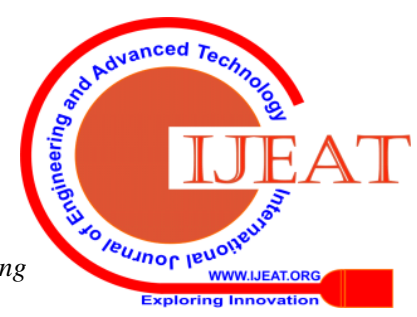




\section{AUTHORS PROFILE}

Dr.Dasarathy A K is a Professor in the Vel Tech Multi Tech Dr. Rangarajan Dr. Sakunthala Engineering College Department Of Civil Engineering where he has been a faculty member since 2016. Currently he is the department Head of the department. He is professor with more than 26 years of experience teaching at the college level and in industry. Distinguished record of publication in academic journals, international \& national conferences all over the world. His research interests lie in the area of transportation ranging from theory to design to implementation. He has collaborated actively with researchers in other disciplines of civil engineering.

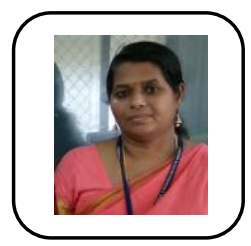

Leela D, born in the year 1974 at Pathanamthitta District, Kerala. Graduated in Civil ngineering from NSS College of Engineering, Calicut University. Post Graduation in Mtech Structures from NIT Calicut. Started career in teaching field in 2001 and continuing till date at Dr. M.G.R Educational and Research Institute.Presently pursuing $\mathrm{PhD}$ from NIT Trichy.

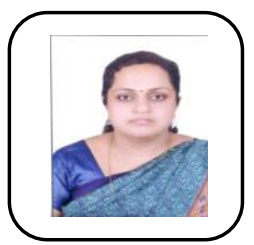

Lekshmi Mohan, born in the year 1980 at Thiruvananthapuram District, Kerala. Graduated in Civil Engineering from TKM College of Engineering, Kollam, University of Kerala. Post Graduation in Mtech Construction Engineering and Management from Dr. M. G. R Educational and Research Institute, Chennai. Pursuing $\mathrm{PhD}$ from the same University. Started career in the field of civil engineering at the maintenance division, VSSC, Dept. Of space, Thumba, for two years. Joined the profession of teaching in 2008 and continuing till date at Dr. M.G.R Educational and Research Institute 